\title{
Collective organisation of knowledge in the early phase of the Dutch-Friesian dairy industry (c. 1880-1914)
}

\author{
Marijn Molema
}

KEYWORDS: dairy chain, knowledge networks, agricultural history, the Netherlands.

JEL CODES: N43, N53, N93, 043.

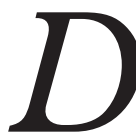
uring the last quarter of the nineteenth century, science and technology opened up new avenues for dairy farmers. Improved techniques for measuring the percentage of fat content in milk and new mechanical production processes had a considerable influence on the dairy production system. However, knowledge was essential to make the most of these opportunities. Historians have offered diverse explanations for the implementation of a knowledge infrastructure within pre-existing dairy networks. Some studies have emphasized the role of individual actors, while others focused on the influence of cooperative structures. This article contributes to the latter and adds a geographical dimension to the organizational history of dairy knowledge. Based on research in archives and newspapers, it investigates two knowledge institutions in the Dutch province of Friesland: a dairy consultancy and a dairy school, both founded in 1889. The conclusion is that the implementation of knowledge institutions was encouraged by the interplay between regional initiatives and national economic policies. 


\section{Organización colectiva del conocimiento \\ en la fase inicial del sector lácteo \\ de Holanda-Frisia (c. 1880-1914)}

\section{PALABRAS CLAVE: cadena láctea, redes de conocimiento, historia agraria, Países Bajos.}

\section{CÓDIGOS JEL: N43, N53, N93, 043.}

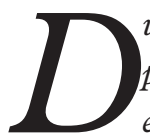

urante el último cuarto del siglo XIX, la ciencia y la tecnología abrieron nuevas posibilidades a los ganaderos de leche. La mejora de las técnicas para medir el porcentaje de grasa en la leche y la mecanización de los procesos productivos tuvieron una influencia considerable sobre el sistema de producción lácteo. Sin embargo, el conocimiento fue esencial para aprovechar estas oportunidades al máximo. Los historiadores han ofrecido diversas explicaciones de la implantación de una infraestructura del conocimiento dentro de las redes lácteas ya existentes. Algunos estudios han enfatizado el papel de actores individuales, mientras que otros se centraron en la influencia de las estructuras cooperativas. Este artículo contribuye a esta segunda línea de investigación, añadiendo una dimensión geográfica a la historia organizativa del conocimiento lácteo. Basado en fuentes de archivo y periódicos, el artículo investiga dos instituciones relacionadas con el conocimiento en la provincia holandesa de Frisia: una consultoría láctea y una escuela láctea, ambas fundadas en 1889. El artículo concluye que la implantación de instituciones relacionadas con el conocimiento fue alentada por la interacción entre iniciativas regionales y politicas económicas nacionales.

Received: 2016-01-18 • Revised: 2017-03-27 • Accepted: 2017-03-28

Marijn Molema leads the FA research group, "Economic clusters, 1870-now", and coordinates the network "Societies in their Environment", of the N. W. Posthumus Institute, the Dutch-Flemish Research School for Economic and Social History. Address: Fryske Akademy, Doelestraat 8, 8900 AB Leeuwarden (the Netherlands). Email:m.molema@fryske-akademy.nl 


\section{INTRODUCTION}

In the late nineteenth century, dairy production in many regions of Europe went through a period of profound change. Mechanical processes driven by steam power opened up new possibilities and challenged traditional farm production methods. Farmers and dairy companies acquired increasing expertise in the properties of milk, which was used as a raw material for traditional products such as butter and cheese and innovations such as condensed milk and milk powder. Dairy production systems became increasingly complex. Therefore, institutions were established, triggering the formation of a network of individuals and organisations which generated and disseminated knowledge (Henriksen, Lampe \& Sharp, 2011). Industrialisation did not mean that contemporaries freed themselves totally from the organisational structures of the past, however. The views held by Beltrán (2012) and Garrido (2007) -that preindustrial social-economic structures and accumulated human capital stimulated the transformation processes needed to cope with modernity-are also true for the agribusiness. This is illustrated here with the help of the Dutch Friesland dairy industry.

This article also explores an additional and often neglected feature: the close interplay between regional initiatives and top-down national government interventions. Recently, rural historians have scrutinized the role of knowledge in modern agricultural growth. Partly based on case-studies of individual actors and institutions, some scholars have identified regional (Segers, 2016) or national (Uekötter, 2010) systems of knowledge dissemination and production. Adding a dimension of geographical interplay between institutions operating on a different geographical scale can increase our understanding of knowledge-driven development. Institutions which were established to cope with technological change are often the result of a collective process in which various actors invest time and money with the goal of lowering the total costs of organising knowledge (Mokyr, 2002). Cooperation between individuals and organisations from provincial and national levels has accelerated these processes, thus stimulating the construction of knowledge for agricultural production and agribusiness.

Friesland provides a suitable case for testing these hypotheses. As a district and since 1815 as a province within the Kingdom of the Netherlands, Friesland is a clearly demarcated region (see Map 1). The internationally most significant sector of its economy is the dairy sector. In terms of land use for agriculture, the province in 1832 occupied $2,551 \mathrm{~km}^{2}$, about $56 \%$ of it pasture and $20 \%$ of it meadows (see Map 2$)^{1}$. Specialisation

1. These numbers are extracted from the historical geographical information system HISGIS (http://www.hisgis.nl/) [Last access on 22 December 2016]. 
in the production of high quality butter started in the early modern period. The formative stage of the Friesian dairy industry took off around 1880 and lasted until the eve of the First World War: by 1914 a solid network of companies and knowledge institutions had been established. Two of these knowledge institutions, a dairy consultant and a dairy school, will be examined in this article.

\section{MAP 1}

The province of Friesland within the Netherlands

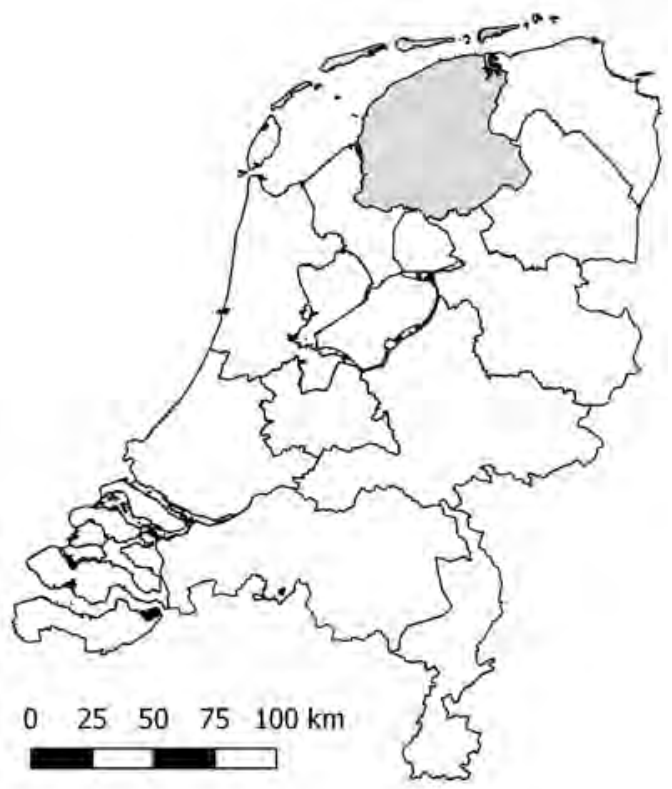

Source: cartography, Thomas Vermaut (Fryske Akademy).

The central question is how the two institutions contributed to the emergence of a knowledge infrastructure for the dissemination of dairy knowledge. Sub-questions enquire into a) what kind of knowledge was actually communicated by the school and the consultant; b) which national and regional structures were responsible for the establishment of these shared facilities in the Friesian dairy sector; and c) to what extent the cooperation of actors from several levels was responsible for the success of these facilities. This study relies on archival research, newspapers and secondary literature. First, the article situates the case study more deeply in its historiographical context. It then embarks on an account of the Friesian dairy industry against the background of the late nineteenth-century international agricultural crisis. Then, the dairy school and the dairy consultant will be considered in two consecutive sections. The final section will bring the two institutions to- 
gether again and briefly address the importance of the geographical dimension in the diffusion of knowledge in rural Europe.

\section{MAP 2}

Land use in the province of Friesland, 1832

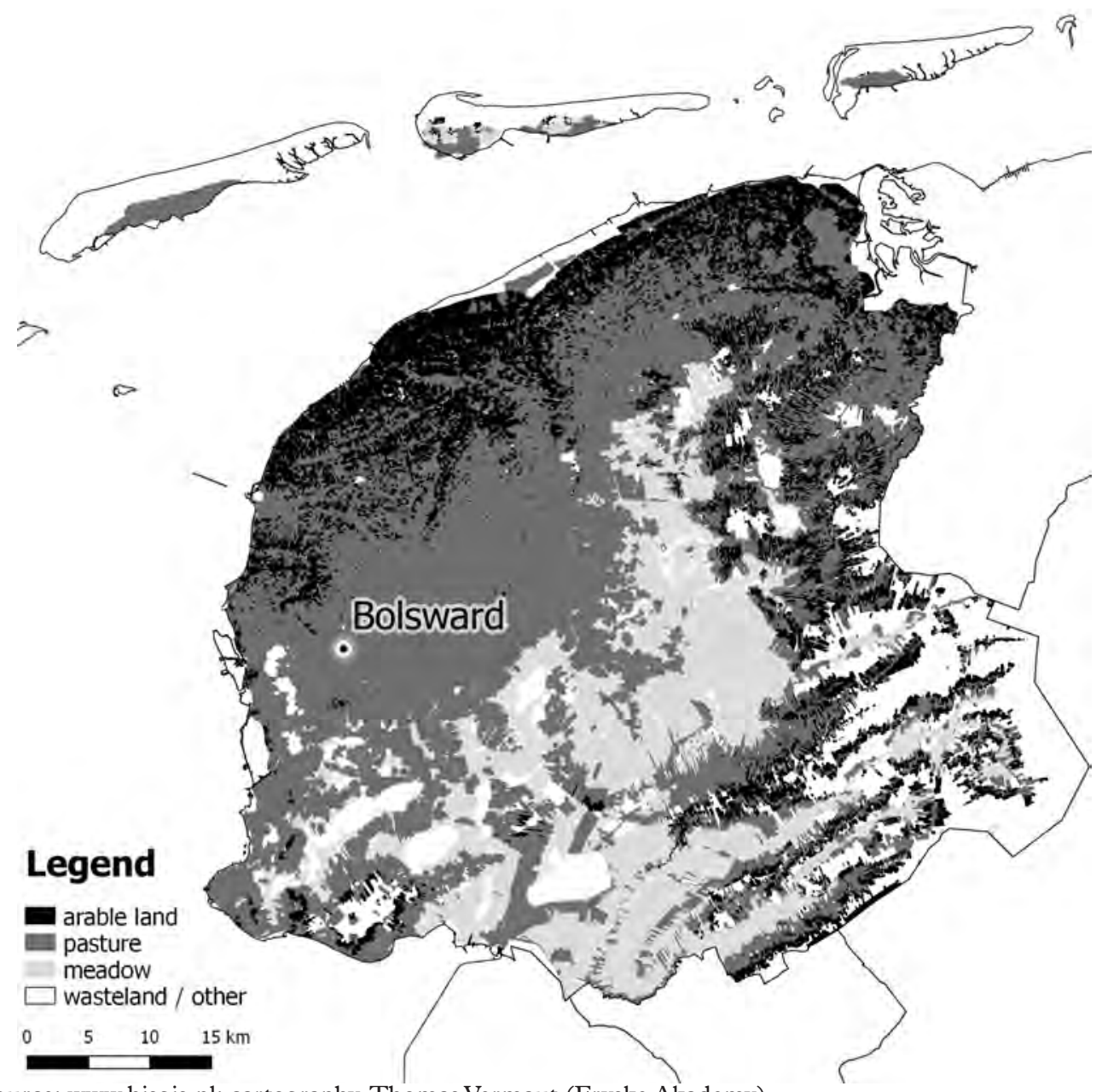

Source: www.hisgis.nl; cartography, Thomas Vermaut (Fryske Akademy).

\section{KNOWLEDGE AND RURAL HISTORY}

The theme of (rural) knowledge is multifaceted in itself. As an analytical object, knowledge can have different forms. Apart from variation in sector/discipline-related knowledge, and the distinction between market and technological knowledge, other categorisations are also relevant. The distinctions between tacit and codified knowledge (Collins, 2010) are well 
known. According to Mokyr (2002: 4) knowledge can be distinguished into prepositional ( $\Omega$-knowledge) and prescriptive knowledge ( $\lambda$-knowledge). The economic geographer Asheim (2012) distinguished between analytical and synthetic knowledge. Analytical knowledge is knowledge which is newly created, which often rests on deductive processes and formal models and is usually codified explicitly (e.g. in patents or publications). Synthetic knowledge is generated by the application or fresh combination of existing knowledge, often rests on inductive processes and is usually tacit (e.g. practical skills). Asheim's conceptualisation helps us divide the historical literature on agricultural knowledge into two strands.

The first strand relates to the category of analytical knowledge, in which new scientific insights are produced. Case-studies of the 1980s and 1990s scrutinized important institutions such as mid-nineteenth century German, French and English agricultural experiment stations (Grantham, 1984; Finlay, 1988). Late nineteenth century laboratories in public hands or financed by companies are also investigated for Belgium (Diser, 2012) as well as England and France (Atkins \& Stanziani, 2008). Other studies investigated academic places of knowledge production, such as the Dutch agricultural university of Wageningen (Van der Haar, 1993) or German agricultural colleges (Harwood, 2005). Jas (2000) and Oberkrome (2009) have analysed national systems of academic knowledge production in Germany and France. One the one hand, these studies form the building blocks of more encompassing studies such as in the German agricultural knowledge history of Uekötter (2010). The many case studies together sketch the outlines of knowledge systems. On the other hand, most of these studies on experiment stations, laboratories and colleges scrutinized the internal tensions in the production of knowledge. Many cases are dedicated to horizontal connections, or relationships between several expert and interest groups. Steere-Williams (2015), for example, analysed the wide variety of experts who competed for authority within the British dairy industry.

The second strand of the historical literature on agricultural knowledge relates to Asheim's synthetic category. Synthetic knowledge already exists, but has to be acquired through learning and practical training. History shows the traces of brokers between the producers and uses of knowledge in all kind of varieties and intermediaries. Several learning institutions have been considered, including farmers' associations and the agricultural press, in which scientific information was popularised through the spoken and written word (Zimmermann, 2010). Agricultural advisors and public or private consultants have also been analysed (De Boer, 2016; Depecker \& Joly, 2015) and illustrated how the gap between experts and lay men was bridged. Finally, the education of young people in schools and colleges has attracted considerable attention (Van Molle, 2005; Segers \& Hermans, 2009; Varga, 2014). The content of these contributions scrutinizes relationships too, 
although on a slightly different way compared to the (institutional) histories of analytical knowledge producers. The interaction between theoretical and practical knowledge is a recurring theme in the studies on associations, particular media, schools, etc. Actors belonging to a similar group or chain of economic activities, discussed into what extent theory really helped agricultural production forward. Proponents of the use of scientific knowledge opposed to more traditional actors, who embraced the pragmatic principle of learning-on-the-job.

Although the first and second strand of the literature on agricultural knowledge has opened up a new and fascinating domain of rural history, there is still space for adding new dimensions which deepens our insight in the role of knowledge in modern agricultural development. One of these aspects is the vertical relationships, or the tensions and connections between actors who are operating on different geographical scales. Some scholars have explored interesting geographical dimensions in the history of agricultural knowledge already. In Sweden, for example, the organisation of agricultural schools was left to local parishes. As a consequence, schools which opened as early as the 1830 s were very unevenly distributed across the country (Nilsson \& Pettersson, 2008). An agricultural school was founded in Italy in 1840 by the Grand Duchy of Tuscany. The educational goals and the curriculum of the school were adapted to the agricultural system in the region (Pazzagli, 2008). These histories link the production and diffusion of knowledge to the specific places where this knowledge was created or diffused. It is exactly this relationship which is disputed in the geographies of science debate (Finnegan, 2008). At the heart of this debate stands the conviction that, if we want to understand the production and diffusion of knowledge, place matters. It was, for example, the geographer Barnes (2003) who argued that Von Thünen's concentric model of agricultural land use was inspired by the daily environment of Von Thünen's homeland, the German state Mecklenburg-Vorpommern. Knowledge creation is related to the individual biographies of the knowledge creators, and the scholar's geographical roots play a role in this. Recently, Livingstone (2010:9) coined the term landscape agency, which refers to the influence of soil, climate, hydrology and demography that play a role in observations and theoretical considerations. It is here that the geographies of science debate show considerable overlap with agricultural history. The natural conditions of a specific place or region are important pieces of basic information for starting any inquiry in agricultural history.

If we look through the geographical lens of science, we could also consider the emergence of knowledge infrastructures in the light of regional initiatives. The roles of climate and the soil are important for constructing any agricultural expertise. The place-baseness of soil and climate often leads to regional specialisations (such as dairy, fruit, olives, seed potatoes, etc.) and alongside this, a concentration of actors with knowledge of these crops. 
Moreover, knowledge infrastructures may be concentrated in specific territories because proximity eases face-to-face contact, which can foster the growth of trust and cooperation between actors (Storper, 1997; Camagni, 2009; Wilson \& Popp, 2003). Agricultural history in general, and historical literature on dairy in particular, has not investigated the emergence of geographically bounded knowledge infrastructure in depth. When studies reconstruct or analyse knowledge infrastructure, the geographical range of these networks are mapped to national territories. Such is the case in the inspirational studies of the Danish dairy industry, which was backed through an agricultural university near Copenhagen and a national network of schools and dairy consultants (Lampe \& Sharp, 2015; Henriksen \& O'Rourke, 2005). In their analysis of the difficult emergence of creameries in Ireland, Henriksen, McLaughlin and Sharp (2015) also reported on regional dimensions, but explanatory links to knowledge-based variables remained absent. The national view on economic development might be so compelling that more regional perspectives find themselves pushed to the wings of historical explanations. This does not further a refined historical understanding.

\section{CRISIS AND INNOVATION}

Although the Industrial Revolution started at different times in different countries, it proved a watershed for the development of agriculture, and from the latter half of the nineteenth century onwards, its effects were noticeable across Europe. Dairy production systems across Europe became part of the agrarian-industrial knowledge society (Auderset, Bächi \& Moser, 2012: 21). The concept was introduced by Swiss historians who wanted to define how industrial and agricultural production methods entered into a symbiotic relationship driven by knowledge. The application of new knowledge-intensive technologies and mechanically powered means of production brought about enormous development. At the same time, practical knowledge was essential to putting the marvels of the Industrial Revolution to use in farming. Institutions such as universities, journals, consultants and associations played an important part in combining old and new types of knowledge. These institutions, not uncommonly subsidised by the government, acted as mediators in uniting industrial and agricultural knowledge. This new knowledge resulted in the rise of new economic sectors which amalgamated agricultural with industrial knowhow into agribusiness (Davis \& Goldberg, 1957). In the northern Netherlands, for example, this was manifested not only in the dairy industry, but also in the sugar and potato starch industries - sectors which were also part of agribusiness.

In the early days of industrialised European dairy production, however, Friesland did not exactly lead the way. The decades before the Industrial Revolution in Friesland were 
exceptionally lucrative. During the third quarter of the nineteenth century, the Friesian town of Harlingen was the foremost Dutch port exporting butter. From there, practically all of the butter produced in Friesland was shipped straight to England ${ }^{2}$. As the population and the living standards in Britain rose, the Dutch increased their exports to the expanding market of London. Farmers and butter merchants in Friesland fared very well from this lucrative trade. In 1870 the total output of Dutch livestock, compared to 1850, had grown by $25 \%$ (Knibbe, 1993: 131). Extensive growth was made possible through new methods of intensification. Grass production rose, and the purchase of fodder produced outside the farm increased. As a result, an average cattle breeder could increase livestock production by 10 to $20 \%$ during the third quarter of the nineteen century. Meanwhile, the average production of each animal rose by about $20 \%$ (Van Zanden, 1985: 224).

The economic achievements of this pre-industrial phase could have made the Friesians less sensitive to external challenges. The rule of the restrictive head start is the most plausible explanation for a hesitant response to market internationalisation processes and technological innovations. Initially, the dairy sector was only indirectly hit by the great agricultural depression, which occurred between 1873 and 1895, and was caused by the swift expansion of agricultural products on the world market (Perren, 1995: 11). Consequently, the prices of cereals declined, followed by meat and dairy products. Structural changes behind the great agricultural depression affected the Friesian dairy sector tremendously. Technological changes launched internal and foreign competition. The invention of margarine, produced from vegetable oils and water, was the most visible. In the early 1870s, two factories were built in the southern Netherlands, which specialised in the production of margarine. These would later become the multinational Unilever company. Friesian dairy farmers kept producing butter manually and complained that artificial butter was sold as "real" butter. They called it adulteration, and called for a quality mark for real butter. Such a quality mark was only introduced on a national scale in 1904. Meanwhile, other countries, especially Denmark, reacted more quickly and forcefully to technological innovations. The Danish dairy producers established a system which guaranteed the quality of their butter (Lampe \& Sharp, 2014), and within a few decades, their butter acquired a strong reputation on the British market. The successes of the Danish butter trade occurred during the 1880s, through new and mechanised systems of production which lowered production costs and guaranteed a uniform product. Table 1 shows how Dutch butter (primarily Friesian butter) became less competitive on

2. According to SPAHR VAN DEN HoEK (1952: part 1, 484), Harlingen exported over 11 million kilograms of butter in 1865. Using Croesen's research (1932: 196), this must be deemed to have accounted for around three-quarters of all Dutch butter exports. 
the English markets. In 1870, its market share amounted to 30\%, but by 1890 this had plummeted to $8 \%$. On their own, these numbers do not prove the decline in total butter production in Friesland. Unfortunately, production statistics for the 1870-90 period were never recorded. However, the total number of Friesian cows, which was recorded, shows a small decline (Table 2).

TABLE 1

Export and import of butter

\begin{tabular}{lrrrr}
\hline & $\mathbf{1 8 6 0}$ & $\mathbf{1 8 7 0}$ & $\mathbf{1 8 8 0}$ & $\mathbf{1 8 9 0}$ \\
\hline Total Dutch exports in million kg & 19 & 22 & 36 & 40 \\
Dutch exports to England in million kg & 18 & 20 & 30 & 29 \\
\% of total Dutch exports to England & $95 \%$ & $93 \%$ & $81 \%$ & $72 \%$ \\
\% of English imports from the Netherlands & $39 \%$ & $35 \%$ & $35 \%$ & $8 \%$ \\
\% of English imports from Denmark & $1 \%$ & $11 \%$ & $13 \%$ & $41 \%$ \\
\% of English imports from France & $12 \%$ & $25 \%$ & $23 \%$ & $26 \%$ \\
\hline
\end{tabular}

Source: Croesen (1932: 192, 195).

TABLE 2

Number of dairy cows

\begin{tabular}{lrrr}
\hline & $\mathbf{1 8 6 8}$ & $\mathbf{1 8 8 2}$ & $\mathbf{1 8 9 5}$ \\
\hline the Netherlands & 893,000 & 879,000 & 904,000 \\
Friesland & 149,000 & 134,000 & 135,000 \\
Friesian share in percentage & $17 \%$ & $15 \%$ & $15 \%$ \\
\hline
\end{tabular}

Source: Knibbe (1993: 142).

The shift of their export trade to other countries and the awareness that other regions had surpassed Friesland in dairy production brought about a sense of urgency which, particularly from 1885 onwards, gathered a head of steam. Slowly but surely, techniques for separating milk mechanically, developed by foreign engineers such as Wilhelm Lefeldt from Germany and Gustav de Laval from Sweden, were implemented (Bieleman, 2009: 28). Technological innovations went hand-in-hand with institutional innovations. This is illustrated by the rise of cooperative factories from 1888 onwards. Of the 166 companies established during the period from 1879 to 1914, 97 were of a cooperative character (Rommes, 2014). Most of these cooperative associations became members of the Union of Cooperative Dairy Factories, which was established in 1897. Statistics from the Union not only reveal a sharp rise in butter production, but also show signs of product differentiation. While the pre-industrial dairy farmers in Friesland mainly produced butter, the dairy companies also became substantial producers of cheese (Knibbe, 1993: 76). 
FIGURE 1

Foundation of private and cooperative dairy companies in Friesland per year, 1879-1914

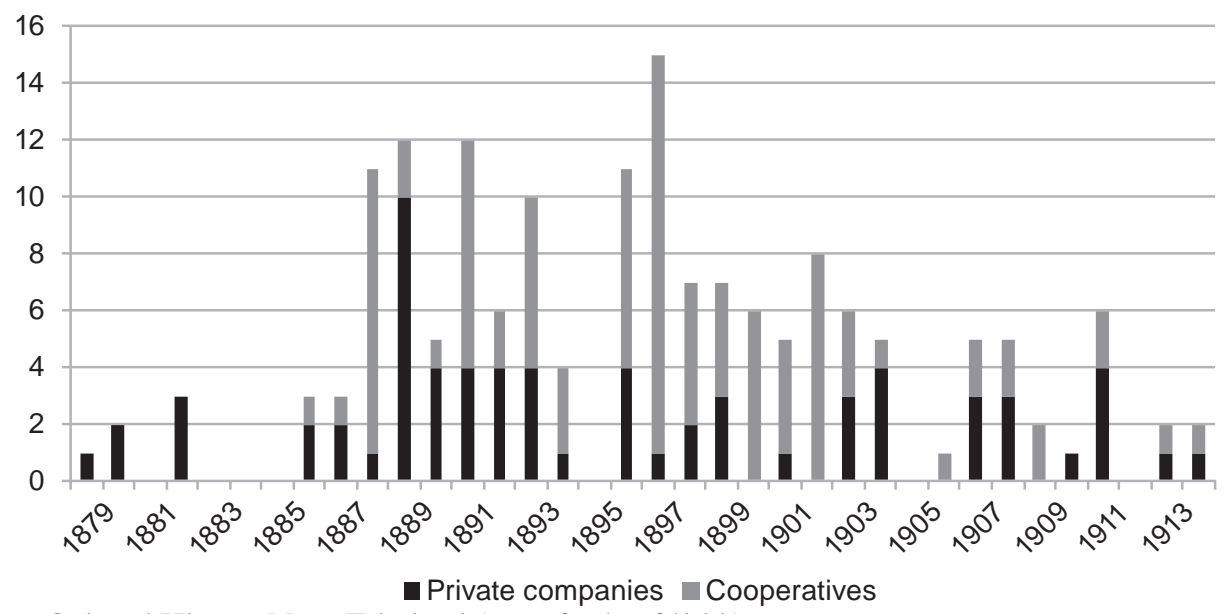

Source: Cultural History Maps Friesland (www.fryslan.frl/chk).

The sphere of concerted action which gave rise to the cooperatives not only flourished among individual farmers and investors. Within the sphere of politics and governance, we can also see the establishment of institutions which would be expected to support the agricultural sector in general. Most visible are the national institutions, which experienced considerable growth in the late nineteenth and early twentieth centuries. As a response to the great agricultural depression which began in 1873, the government appointed a Committee for Agriculture in 1886. Until 1890 this Committee made twelve recommendations to the government on measures to develop Dutch agriculture. The Committee's proposals proved to be a catalyst for measures and state initiatives in the area of agricultural education, consultation and laws to improve quality measures. An institutional matrix emerged, which helps us to capture the complexity resulting from the dense sets of relationships that can exist between a multitude of state and non-state actors and forces (Schuurman, 2013: 67). In this institutional matrix, we should not overlook regional institutions, which were often precursors to national institutions. At a regional scale, individuals were already organised into agricultural societies, one of which was the Friesian Agricultural Society.

\section{CONSULTANCY AND STRATEGIC ADVICE}

Both the dairy school and the dairy consultancy were founded on an initiative of the Friesian Society for Agriculture and Stock Breeding (Friese Maatschappij van Landbouw en 
Veeteelt: "the Society"), founded in 1852. Two years after its establishment, half of its almost 1200 members were farmers, most owning their own land (Spahr van den Hoek, 1952: part 2,54). Approximately $20 \%$ of the members were land and estate owners, and the other $30 \%$ were a diverse category of traders, teachers, craftsmen or manufacturers, but also a small number of notables, such as veterinarians and clergymen. Thus, as an institution, the Society was not an organisation of farmers alone, but one which supported agriculture and cattle-breeding in general. According to the regulations, one of the Society's goals was the dissemination of agricultural knowledge. This explicit reference was no surprise, because the Society was a continuation of the Friesian Society for Experimental Agriculture, founded in 1843. In keeping with European traditions (Goddard, 1981), the Society organised fairs featuring exhibitions of farming equipment and cattle judging. The Society also had its own periodical, in which it published pieces on current issues and meeting reports. Meetings were important at a provincial level, but also for the fourteen districts. In addition, the Society organised lectures on various agricultural and political subjects, which the members discussed in their district meetings. Connected to the problems of the agricultural depression, the themes discussed became more political during the 1870s and 1880s. It was not uncommon for the Society to influence economic policymaking, particularly because several of the Society's board members also held seats in the provincial government and on national committees. One example is D. Fontijn de Jong, president of the Society from 1882 until 1895. He also served as MP in the provincial parliament and was a member of the influential national Committee for Agriculture (1886-90). Due to its political activities, membership rose, as did the percentage of farmers who joined the Society in particular: fewer than $10 \%$ of farmers are estimated to have been members of the Society in 1866 , which increased to about $17 \%$ in 1880 (Spahr van den Hoek, 1952: part 2, 66). Compared to other countries and regions, it was remarkable that the Society's position was not threatened by new organisations. Rival farmers' organisations, inspired by religious and/or political ideologies, only entered the stage in Friesland after the First World War (Van der Woude, 2004).

One example of the politicised initiatives undertaken by the Society is its call for education. At first, the Society aimed to recruit a travelling educator of some kind. They invited D. N. L. Gäbel, dairy farmer and leader of a dairy school near Flensburg (northern Germany) to offer farmers advice and demonstrations in the summers of 1881 and 1882. From 1885 onwards, the Society considered establishing a school of agriculture, and a few years later, it argued for the recruitment of a consultant. The example was set by Denmark: from 1860 to 1880, Dr.T. R. Segelcke (1831-1902) was hired by the Royal Danish Agricultural Society as a dairy consultant. In this role, and later as a professor at the Royal Veterinary and Agricultural University of Frederiksberg -which opened its colleges in 1858 near Copenhagen (Skrubbeltrang, 1953: 136)- Segelcke played a pivotal 
role within the Danish dairy industry. His achievements included developing new accounting methods, which he taught as well. The inputs and outputs of dairy farms and butter producers needed to become subject to closer scrutiny, which facilitated systemic evaluations and improvements. It fell to another Dane, Vilhelm Carstens, to draw the attention of the members of the Society to the Danish institutes. Carstens was married to a Friesian woman and was director of a dairy company in the Friesian town of Sneek. As such, he joined the Society and became a proponent of dairy education.

In March 1887, Carstens made an appeal to the Society's board, which reflected the urgent need for change: One is unaware of the demands this modern day and age place upon dairy producers, in view of the competing nations surrounding s $^{3}$. Carstens found Friesian farmers to be overly attached to traditional methods of production and, as a result, other nations had outpaced Friesland. Only the wholehearted acceptance and application of new techniques would allow Friesland to catch up with the competition:

Seeing that recent scientific research and industrial advancements have supplied the farmer with a number of hitherto unheard of aids, it simply cannot be that he remains ignorant or unknowledgeable of these aids. It is a necessity for every farmer to delve into this research and to use it to his best advantage ${ }^{4}$.

Farmers needed a consultant to advise and assist them to advance the application of knowledge and new methods. This consultant would completely commit himself to the Friesian dairy sector. The few opponents to this plan accused forces outside the province of causing Friesland's impoverishment in the market: margarine being exported as real butter had damaged the reputation of Friesian butter. However, six of the fourteen departments were in favour of the idea ${ }^{5}$, and so in 1889 the Society hired a dairy consultant. The costs of this consultant consumed one-third of the Society's budget, but the bulk of his salary was paid with subsidies from the provincial and national governments.

The Society expected its consultant to advance dairy production by doing research, the direction of which he could determine himself. The Society also expected him to deliver lectures, advise farmers and dairy producers and write pieces for the periodical, the Society's platform. The first consultant, Dr. Karel van der Zande, spent most of his time

3. Frysk Histoarysk en Letterkundich Sintrum (TRESOAR), Agricultural Society, FAS/269, Inv. No. 2351, letter from V. Carstens to the Board of the Friesian Agricultural Society, March 1887.

4. Ibid.

5. TRESOAR, FAS/269, Inv. No. 2351, letter from Society president D. Fontein de Jong to the Society board, undated. 
on the nutrition of cows ${ }^{6}$. In 1892 he became the director of the national dairy test station, located in the province of North Holland. His successor, Johannes Mesdag (18501932), occupied the position until 1930 and, thanks to his ceaseless efforts, became the leading figure in Friesian dairy research. Like Van der Zande, Mesdag advised individuals and dairy factories, published countless articles on a wide variety of subjects and soon took seats on all kinds of committees and boards, including those of the dairy school. Mesdag continued his research where his predecessor had left off, researching fat percentages in milk. Both men had been educated as chemists and both had visited Denmark to prepare for their work as consultants. In Denmark, they had met Professor Segelcke and had been introduced to precise methods of monitoring milk production.

The consultants soon learned that the key to improving the production of butter and cheese was to increase the milk's fat percentage. This could be achieved by breeding the cows with less regard for personal gut feelings and the cows' appearance, and more focus on their productivity (Theunissen, 2008). However, a specific kind of knowledge was needed for the determination of fat percentages, and the methods for doing so had been developed during the mid-1850s but were complicated and expensive (Atkins, 2010: 7581). In 1892, the Swiss chemist and industrial entrepreneur N. Gerber (1850-1914) developed a technique which was quicker and cheaper than all the others. He called his technique acid butyrometrics. This nomenclature refers to the generic name for all acid chemical constitutes (acids) and the Greek word for butter (butyros). By adding 10 centilitres of sulphuric acid and 1 centilitre of alcohol to 11 centilitres of milk, the fat in the milk would become visible (Schey, 1903: 4; Gerber \& Schneider, 1938: 18-28). The amount of fat could be measured using a special test-tube which Gerber successfully marketed: the butyrometer.

Acid butyrometrics became the chief method for separating milk and Mesdag used it too. In 1894 he started research into three herds of cattle kept on farms across the province. By regularly writing about this process in the Society's periodical, Mededeelingen en Berichten, Mesdag sought to inform and convince his readers ${ }^{7}$. Neat tables such as Table 3 below, proved that the fat percentage could differ considerably per cow. Farmers who did not pay attention to this ran the risk of losing income. However, Mesdag did not deal with the producers alone; he also encouraged the factory managers to implement changes to their payment methods. Rather than price on the basis of the quantity of milk sold, they priced on the percentage of fat. This would also protect factory managers against

6. TRESOAR, Provincial Government, PG/11, Inv. No. 5740, annual report of Dr. K. van der Zande, 1890.

7. See the Society's periodical, Medeelingen en Berichten, especially between 1894 and 1896. 
cheating farmers, who diluted their milk with water or sent milk which had just been separated -and often returned- straight back to the factory. To spread dairy-making knowledge and know-how, Mesdag organised courses for farmers and dairy factory personnel. He collaborated with other organisations, such as the Fries Rundveestamboek (Friesian Pedigree Book), which saw Mesdag's research as an opportunity to further improve the pedigree of Friesian cows. Furthermore, his study was also integrated within the dairy school's curriculum.

TABLE 3

Dr. Mesdag's early measurements, 1894

\begin{tabular}{lrrc}
\hline Cow no. & KG milk & KG fat & Fat percentage \\
\hline 6708 & $3,862.0$ & 132,144 & 3.42 \\
7126 & $3,961.5$ & 82,021 & 2.07 \\
5887 & $4,244.5$ & 116,048 & 2.73 \\
7125 & $4,426.8$ & 120,062 & 2.71 \\
7129 & $4,441.0$ & 147,190 & 3.32 \\
6709 & $4,482.5$ & 133,143 & 2.97 \\
\hline
\end{tabular}

Source: Mededeelingen en Berichten, 15th February 1895.

\section{EDUCATION AND PRACTICAL TRAINING}

In 1887, Carstens began calling for both a dairy consultant and a dairy school to be funded, but the debate about agricultural education continued for some years after that. Eventually, the debate centred on the examples set by the French and German schools (Bruinsma et al., 1884). The German arable farming schools (Ackerbauschulen) and the French agricultural schools for vocational training (Les écoles practiques d'agriculture) had been deliberately established as schools which combined theory and practice. Slowly but surely, the foundation of a school was linked to international competition among dairy producers. In 1885, one of the Society's board members became a firm proponent of education in mechanical technologies, which he considered the fruits of scientific knowledge ${ }^{8}$. He referred to the declining exports to England and the rise of producers in northern Germany, and even more so, in Denmark. The creation of the Friesian dairy school was one way of catching up on the competition. The decision to start a school was finally taken in the spring of 1886 . The week before, the periodical had even published an article on the subject: it dealt with dairy schools in Denmark, Mecklenburg, Prussia, Oldenburg and

8. Memo Van Konijnenburg (1885). Mededeelingen en Berichten, (18), 24. 
Hannover 9 . Thus, the Friesian school was founded upon their example, with the aim of improving the Friesian position in the international market.

However, not all of the Society's members were equally convinced by this idea. At meetings, some members were convinced that there was no real need for theoretical knowledge ${ }^{10}$. Practical knowledge, however, was deemed essential, but could be acquired just as effectively on a farm. After all, that kind of knowledge had been passed on for generations. The opponents of the school did not see how theoretical knowledge could introduce a new production regime. Meanwhile, however, the first dairy factory in Friesland had been opened in 1879, and by 1898 Friesland had more than 100 factories: mechanical dairy production had come to dominate the market. Thus, by the mid1880 s, the onsite teaching of the manual production process was about to become marginalised. Since many of the Society's members remained unaware of this development, and those criticising the dairy school did not hesitate from voicing their opinions, the school and its curriculum remained a halfway house between the old and new production processes.

Nevertheless, the idea of founding the school was embraced by the provincial and national governments, who subsidised it to the tune of NLG 1000 (22\% of the annual budget) and NLG 2000 (44\% of the annual budget), respectively ${ }^{11}$. By the late nineteenth century, politicians no longer shied away from agricultural affairs and instead pursued the topic more actively (Schuurman, 2013). The Friesian request for a subsidy for the dairy school was sent to the Committee for Agriculture, who advised positively and, motivated by this bottom-up initiative, published a more comprehensive set of recommendations about agricultural education in general ${ }^{12}$. Embedded into the emerging structures of statesponsored agricultural education, the Friesian dairy school opened its doors in 1889. The first cohort of students comprised eight farmer's sons from the surrounding area. In the small town of Bolsward, in western Friesland, these students followed an intensive threemonth course which provided them with practical training in the mornings and theory in the afternoons. The milk which arrived every morning was to be processed immedi-

9. Author unknown, Improvements in Dairy Production in the Interest of the Province, addendum to the Society's periodical, 15 February 1885.

10. The protocols of the meetings and other documents on which this section is -to a large extentbased, are kept in the archive of the dairy school, which was stored in Deventer at the Ministry of Economic Affairs and not inventoried at the time the research for this article was conducted. We will refer to it as the Archive of the Dairy School (ADS).

11. NA, Ministry of Internal Affairs, 2.04.10/683, Financial report 1890 Dairy School.

12. Advice about the Desirability of State Subsidies for Schools of Agricultural Vocational Training, Staatscourant, 14 May 1887. 
ately by the students, under the guidance of the school's headmaster. Each pair of students, aged 22 on average, was responsible for a specific task. To that end, the production process had been divided into four stages: 1) measuring the quantity and quality of the incoming milk; 2) separating the milk; 3) churning the milk and creaming the butter; and 4) preparing fresh cheese and checking previously prepared cheeses. The students received instruction on gathering, processing and analysing data at every stage of the production process, so that they also became grounded in discharging their administrative duties. In the afternoons, the headmaster instructed them on subjects closely related to dairy production. He would teach them about the nutritional needs of cattle by giving lectures on natural science, botany, zoology and physics. When he was not advising farmers and dairy factories on behalf of the Friesian Society of Agriculture, the dairy consultant taught classes in chemistry. By 1892, 81 students, including three women, had been educated in this way ${ }^{13}$.

Along with teaching its students the mechanical process for separating milk, for which it used a centrifuge made by the Swedish company Laval, the dairy school also taught its students how to do this manually in the old-fashioned way. For this, the students had to use setting pans, which were made of wood at first, and later on of copper. The milk was left overnight, with the cream scooped off and churned into butter the following day. This shows the dual character of the dairy school: students had to be taught both the old manual techniques and the new mechanical ones, thus underscoring the transformative stage that the Friesian dairy production system found itself in. The modernity of the Friesian dairy school thus had its limits.

The results of this ambivalence slowly began to show: when the first class of pupils had all accepted position at dairy factories, it soon became apparent, from critical feedback from the dairy companies, as well as from the students and their parents, that the pupils lacked knowledge. The students and their parents had assumed the courses to be sufficient preparation to fill an executive position at a dairy factory. However, due to the programme's ambivalent nature and limited length, these expectations could not be met (Molema, 2016). A reorganisation of sorts in 1893 did not manage to resolve these issues. Even when the school had decided to lengthen the duration of the programme and to educate students as factory workers, the school continued to be criticised. In 1898, another reorganisation occurred. The school's emphasis on mechanical production processes was reinforced by its decision to focus entirely on theoretical education. This meant that the school would no longer process large quantities of milk into butter and cheese. The students would be educated to become factory managers. Moreover, the entry requirements

13. ADS, dairy school students' roll 1889-89. 
were made stricter: students needed to have at least one year's experience working at a dairy factory, so that they would already have the necessary practical skills.

Notwithstanding these clear ambitions, the dairy school lost its independence, with ownership passing into the hands of the state. Partly due to the work of the Committee for Agriculture, the government began to increasingly involve itself with agricultural education (Kooij, 2008). Schools were regarded as the chief means for building a countrywide knowledge infrastructure to benefit the agricultural sector. From 1898 on, a designated state department busied itself with the advancement of agricultural education. The mounting ambitions of the state contrasted with the speed at which the dairy school in Bolsward changed its curriculum. If the dairy school had reorganised sooner and had there not been a dispute over its location, the school might have maintained its independence. Nevertheless, the provincial government, which had previously subsidised the school, advocated a state school to the government ${ }^{14}$. The State's Commissioner, the highest official in the Dutch provinces, blamed the school's private ownership for unresponsiveness. In 1900, classes at the dairy school were suspended as a result of the Friesian Commissioner's disapproval and the ambitions of federal officials. Meanwhile, the government prepared the opening of a new school, which, under pressure from parliament, would remain in Bolsward. On 1 October 1904, the State dairy school admitted its first ten students ${ }^{15}$.

The question of how the "old" school's problems were solved now arises. Firstly, its admission requirements were made stricter: students had to have at least 18-month work experience working in a dairy factory and also had to take an exam. This permitted the school to select a student body possessing both practical experience and theoretical grounding. Secondly, the school programme now took 18 months to complete and had been split into three semesters, during which the students took theoretical classes. In the summer holidays, the students also did an internship at a dairy factory to improve their practical skills. The emphasis was on theory, but without losing sight of the practical side of dairy production. The subjects on its curriculum made clear that the school intended to prepare its students for managerial positions within the dairy industry. Commercial communication, therefore, was deemed important: commercial communication in Dutch was a mandatory subject, and in addition, the school offered commercial communication in German, French and English as free electives. Accounting and commercial arithmetic were separate subjects, instructed by a tutor. Finally, three tutors taught classes in subjects explicitly concerned with dairy production. One tutor taught chemistry, physics and

14. NA, Ministry of Internal Affairs, 2.11.35/36, Commissioner of the King to the Minister of Internal Affairs, 17 May 1900.

15. ADS, dairy school students' roll 1904. 
mathematics, another taught nutrition and animal health, and the headmaster taught dairy preparation and bacteriology. Therefore, apart from offering general subjects aimed at language and mathematics, the curriculum was also firmly rooted in the natural sciences. This would ensure the students became tomorrow's leaders in the dairy industry.

\section{NODES OF KNOWLEDGE}

The previous two sections have shown how the dairy consultant and the dairy school laid the foundations for the knowledge infrastructure within the Friesian dairy industry. Both the dairy consultant and the school continued their activities. Dr. Mesdag retired in 1930 and was not replaced. Because of the thoroughness of his own work, the appointment of a new dairy consultant was regarded as superfluous. The dairy school, however, survived for almost the entire twentieth century. After the Second World War, it adapted its curriculum to new techniques such as process automation and, from the 1970s onwards, IT innovations (Hemink et al., 1979). The school only lost its independence in 1996 when it was forced to merge with a more comprehensive institute of agricultural education in Leeuwarden, the capital city of Friesland. Looking back on the organisational history of both institutions, we can identify their pioneering work in the formative stages of the Friesian dairy industry, which ended on the eve of the First World War. What role did the two institutions play in the rise of this sector? To answer this question, we should look at the number of people educated by the dairy consultant and the dairy school first. From 1896 on, the dairy consultant trained dozens of people in the techniques of milk fat measurement (see Figure 2). Mesdag's trainees became independent knowledge workers in the Friesian dairy production system.

While Mesdag's courses were aimed at training on the job, the dairy school educated young people. In its first ten years (1889-99), the dairy school delivered about 25 graduates a year. About ten students a year were enrolled from 1904 on and most completed the school programme. Table 4 presents the professions of 166 people in 1926 who had successfully completed the programme, with the great majority of the graduates holding responsible positions in the dairy industry. Of the 166 alumni, 63 were working in Friesland in 1926. This proportion illustrates that it would be exaggerated to speak of a single regional knowledge institute. In fact, individuals and organisations coming from or connected to Friesland maintained relationships with other regions throughout the Netherlands and Europe. The dairy school, for example, actually became an important supplier of the national dairy industry. However, the pioneering role of knowledge institutes concentrated in one region still underscores the geographical dimension of agricultural knowledge development. 


\section{FIGURE 2}

Dr. Mesdag's milk testing courses: number of course participants, 1896-1930

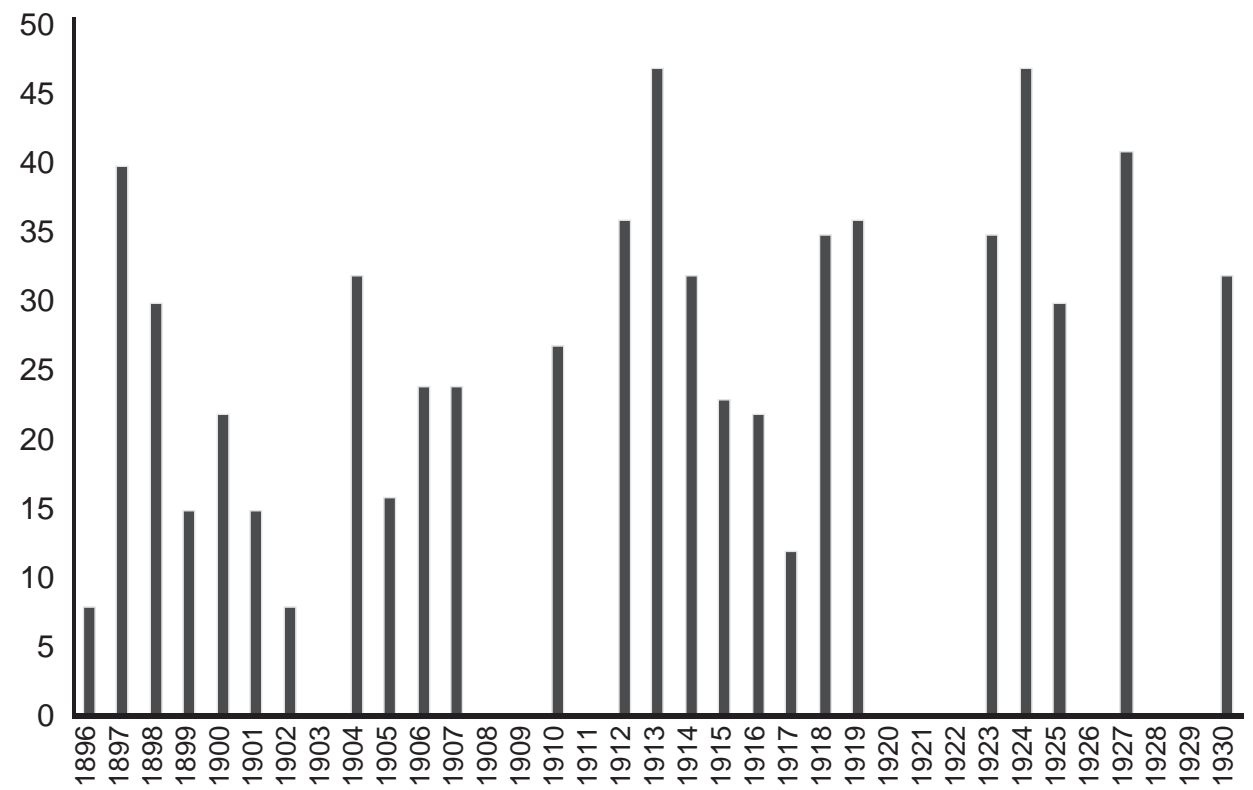

Source: De Boer (2016). The data for 1903, 1908, 1909, 1920-22, 1928 and 1929 are lacking.

TABLE 4

Professions of graduates from the Dairy School in 1926

\begin{tabular}{lr}
\hline Function & \\
\hline Assistant or manager dairy industry & 39 \\
Director dairy industry & 85 \\
Teacher & 3 \\
Dairy interest organisation & 11 \\
Technician & 4 \\
Trader & 7 \\
Other & 17 \\
Total & $\mathbf{1 6 6}$ \\
\hline
\end{tabular}

Source: Database R. Plantinga based on Krediet and Staal (1926: 28-33).

A brief comparison with other parts of the Netherlands and Europe will make this dimension clearer. Firstly, another part of the dairy industry in the Netherlands was concentrated in the southern Netherlands. Here, more than 50 years after the foundation of the dairy school in the north, another school was opened in 1948 in the centre of Den Bosch. The time difference can be explained by reference to the level of dairy farming and 
the structure of the dairy industry. The starting position of dairy farmers and companies in Friesland was far better compared to the south, where more peasants lived and where the dairy companies were initially driven by hand separators (Dekker, 1996). Secondly, literature on the cooperative dairy industry in Ireland (Henriksen, McLaughlin \& Sharp, 2015) points to the concentration of companies in the South (Golden Vale) and the North, but relationships with knowledge institutions in both regions remains to be explored more intensively. Thirdly, a clear contrast to the Dutch-Friesian situation can be found in Denmark. Here, a national system of eight dairy consultants and one national agricultural university was established, which served the whole country: its organisation was top-down and led by the national government (Henriksen \& O'Rourke, 2005).

Another approach understands the importance of knowledge institutions from the perspective of their origins in regional agricultural traditions. Metaphorically, we can see Mesdag's trainees and the dairy school's graduates as "nodes of knowledge" within the expanding network of Friesian industrial dairy production. They gained an independent position in the dissemination of scientific knowledge, something which was backed by their relationships to other organisations within the institutional matrix. For example, many of the knowledge workers must have supported the work of the herd-book organisations. As in other regions and countries (Hernández Adell \& Pujol, 2016), a Friesian Herd Book was established in 1879. Its aim was the biological improvement of cattle. Apparently, the criteria for improvement were based on health and the amount of milk the cows produced. The quality of the milk became a new and important benchmark for a "good cow". From the late nineteenth century on, the percentage of milk fat became the guiding principle in the improvement of herds: cows which lagged behind the general percentages were sold and/or slaughtered, while the cows and bulls with better track records were used for breeding. Those individuals who learned the skills of milk fat measurement must have played leading roles in the local milk control societies, which were also founded throughout the province of Friesland in the late nineteenth century. Associations took on responsibilities for the organisation of the measurement procedures on farms, which were standardised and professionalised. Finally, we should not forget the financial stimuli offered by dairy companies. In the formative stage, all companies paid their farmers for the amount of milk sold. However, in the 1890s, the first directors changed their payment procedures and also took the milk fat into account. This shift was a direct effect of the dissemination of science: those individuals and organisations who had acquired new knowledge changed the "rules of the game". Farmers were not only encouraged to produce more milk, but also better milk.

Notwithstanding these positive trends, we cannot give a final evaluation of the role played by knowledge institutions. On the one hand, more research is necessary on the 
adaption of new technologies. This was a complex process, in which not all farmers and dairy companies were early adaptors - probably, many contemporaries were sceptical towards the "fruits of science". On the other hand, it is difficult, if possible at all, to measure the impact of knowledge workers on increasing labour productivity and economic growth. Statistics on the rise of fat percentages are, currently, only sporadically available. The impact of knowledge and technology in the rise of dairy production has been investigated by some scholars (Henriksen, Lampe \& Sharp, 2011); however, more studies are needed to link the contribution of knowledge workers to the quantitative and qualitative improvement of agricultural production. On the basis of our analysis, we can strengthen our assumption that an increase in dairy production would not have been possible without people who knew the laws of chemistry and could apply techniques for measuring fat in milk. In this sense, the dissemination of dairy knowledge by both the consultant and the school significantly contributed to modern economic growth. Although their scientific training was in most cases elementary, those involved became familiar with a body of fundamental knowledge. As a consequence, farmers and farmers' sons, other individuals accredited by the dairy consultant and graduates from the dairy school, all contributed to the adoption of industrial dairy production methods. They became key players in the agrarian-industrial knowledge society: as improvers of cattle breeding methods, as proponents of milk payment systems on the basis of fat percentages, and as senior executives of dairy companies. Many handed down knowledge within this group of early knowledge workers, for example as milk fat testing instructors or as "trainers on the job" in dairy companies. Some of the dairy school's earliest students, such as S. Hepkema and S. Nijholt, who both graduated in 1907, took leading positions in the Friesian dairy industry. Hepkema became the first director of the Friesian cooperative multinational in condensed milk, and Nijholt became director of the Friesian export organisation (Frico). As captains of industry, these men were at the forefront of the generation educated between around 1890 and 1910. During this period, a body of collective knowledge was created and applied to innovate.

\section{CONCLUSION AND DISCUSSION}

This contribution analysed the emergence of a knowledge infrastructure within the dairy industry of Friesland, a province of the Netherlands. We have seen that theoretical and practical knowledge generated elsewhere was disseminated by a dairy consultant and a dairy school. Farmers and their children, as well as directors and dairy company staff, were introduced to practical applications of physics and chemistry in the industry, such as the measurement of fat percentages in milk. Within the dairy school, managerial skills such as accounting and business correspondence were also taught. This article has shown that 
the emergence of a knowledge infrastructure was encouraged by the interplay between regional initiatives and national economic policies. Participation at both the provincial and the national levels was needed: the interplay between the two levels of activity was responsible for the success of the knowledge institutions. On the one hand, the national government profited from the regional ambitions in Friesland, which were useful to the implementation of the emerging national policy on agricultural development. This policy was formulated after the agricultural depression of the 1880s. However, given that at the time there was only a small state apparatus for agricultural education, the state was dependent on regional initiatives. On the other hand, provincial initiators needed the financial resources of the national government, and civil servants from the national government also proved to be crucial advisors. The first and private dairy school (1889-99) failed because of the hesitant stance towards modernisation within the Friesian Society for Agriculture and Stock Breeding, which founded the school. Only the decisive adoption of theoretical education was able to meet the social need for leaders in the emerging dairy industry. The region needed the state to take this uncompromising decision.

However, the Society should not be discounted as an institution which only obstructed Friesland from adopting modern systems of dairy production. In fact, the Society provided both a fundament and gave the first incentive for the dissemination of scientific knowledge in the early phase of the Friesian dairy industry. Here the Friesian case links to the debate on preindustrial social-economic structures and accumulated human capital, as briefly mentioned in the introduction. Garrido (2007: 196) isolated a layer of medium-sized farmers as an important factor of successful cooperation -which was only sporadically the case in Spain because of the powerful position of large farmers who adopted a free rider behaviour, thus undermining the local cooperatives of the early twentieth century. Beltrán (2012: 512) develops Garrido's argument further by emphasizing the impact of the pre-existing stock of social capital on the willingness to cooperate. Referring to the Spanish history of common lands and irrigation communities, Beltrán points at social traditions in which trust and social networks offered the fundament for modern cooperative projects. Both arguments are true for the collective organization of Friesian dairy knowledge too. A balanced structure of landed property, divided among many middle-sized and specialized dairy farmers, resulted in a vigorous Society; it was the embodiment of a regional sense of self-confidence. The Society accumulated decades of experience with political lobby and discussing agricultural interests. Without this basis, the first incentives for knowledge institutes would not have been formulated at the end of the nineteenth century.

As this article shows, however, the success of regional cooperative initiatives is dependent on national circumstances too. This case study of educational networks in Fries- 
land emphasises the importance of relationships between the regional and national levels. Future research might explore these relationships further, comparing regions within different countries in greater depth, to better grasp the influence of different economic, political and cultural systems.

\section{ACKNOWLEDGEMENTS}

I am grateful to the peer reviewers of Historia Agraria for their useful comments, as well as Fernando Collantes for his stimulating feedback while working on this article. I also thank my colleagues Thomas Vermaut (cartography), Ronald Plantinga and Sjoukje de Boer (data-collection).

\section{REFERENCES}

AsheIM, B. (2012). The Changing Role of Learning Regions in the Globalizing Knowledge Economy: A Theoretical Re-Examination. Regional Studies, 46 (8), 993-1004. Atkins, P. (2010). Liquid Materialities. A History of Milk, Science and the Law. Farnham: Ashgate.

AtKins, P. J. \& Stanziani, A. (2008). From Laboratory Expertise to Litigation. The Municipal Laboratory of Paris and the Inland Revenue Laboratory in London, 1870-1914: A Comparative Analysis. In C. RABIER (Ed.), Fields of Expertise: A Comparative History of Expert Procedures in Paris and London, 1600 to Present (pp. 317-38). Newcastle upon Tyne: Cambridge Scholars Press.

Auderset, J., BÄCHI, B. \& Moser, P. (2012). Die agrarisch-industrielle Wissensgesellschaft ium 19./20. Jahrhundert: Akteure, Diskurse, Parktiken. In B. BRodBECK, M. INEICHEN \& T. SCHIBLI (Eds.), Geschichte im virtuellen Archiv: Das Archiv für Agrargeschichte als Zentrum der Archievierung und Geschichtsschreibung zur ländlichen Gesellschaft (pp. 21-38). Baden: Hier + Jetzt.

BARnes, T. J. (2003). The Place of Locational Analysis: A Selective and Interpretive History. Progress in Human Geography, 27 (1), 69-95.

Beltrán, F. J. (2012). Commons, Social Capital, and the Emergence of Agricultural Cooperatives in Early Twentieth Century Spain. European Review of Economic History, 16 (4), 511-28.

Bieleman, J. (2009). The Emergence of Mechanized Dairying in the Northern Netherlands, and particularly in the Provinces of Drenthe and Friesland. In Y. SEGERS, J. BIELEMAN \& E. Buyst (Eds.), Exploring the Food Chain: Food Production and Food Processing in Western Europe, 1850-1990 (pp. 17-48). Turnhout: Brepols. 
Bieleman, J. (2010). Five Centuries of Farming: A Short History of Dutch Agriculture 1500-2000. Wageningen: Wageningen Academic Publishers.

BRUINSMA, V. et al. (1884). Een Landbouwschool in Friesland. Rapport aan het Hoofdbestuur der Friesche Maatschappij voor Landbouw over de vraag: Hoe Friesland op de beste wijze kan geraken in het genot van theoretisch en practisch landbouwonderwijs? Mededeelingen en Berichten, 17 (2), 8-44.

CAMAgni, R. (2009). Territorial Capital and Regional Development. In R. CAPELlo \& P. NiJKAmp (Eds.), Handbook in Regional Growth and Development Theories (pp. 11832). Cheltenham: Edward Elgar.

Collins, H. M. (2010). Tacit and Explicit Knowledge. Chicago: University of Chicago Press.

Croesen, V. R. IJ. (1932). Geschiedenis van de ontwikkeling van de Nederlandsche zuivelbereiding in het laatst van de negentiende en het begin van de twintigste eeuw. 'sGravenhage: N.V. Boek- en Kunstdrukkerij V/H Mouton \& Co.

Davis, J. H. \& Goldberg, R. A. (1957). A Concept of Agribusiness. Boston: Harvard University.

De BoeR, S. (2016). Bruggenbouwer tussen wetenschap en praktiik: De zuivelconsulent in Fryslân rond 1900. DeVrije Fries, (96), 127-44.

DeKKer, J. C. (1996). Zuivelcooperaties op de zandgronden in Noord-Brabant en Limburg, 1892-1950: Overleven door samenwerking en modernisering. Een mentaiteitsstudie. $\mathrm{PhD}-$ thesis. Tilburg University.

DepeCKer, T. \& Joly, N. (2015). Agronomists and Accounting: The Beginnings of Capitalist Rationalisation on the Farm (1800-1850). Historia Agraria, 65 (2), 75-94.

DisER, L. (2012). Laboratory versus Farm: The Triumph of Laboratory Science in Belgian Agriculture at the End of the Nineteenth Century. Agricultural History, 86 (1), 31-54.

FINLAY, M. R. (1988). The German Agricultural Experiment Stations and the Beginnings of American Agricultural Research. Agricultural History, 62 (2), 41-50.

FinNegan, D. A. (2008). The Spatial Turn: Geographical Approaches in the History of Science. Fournal of the History of Biology, 41 (2), 369-88.

GARRIDO, S. (2007). Why did Most Cooperatives fail? Spanish Agricultural Cooperation in the Early Twentieth Century. Rural History, 18 (2), 183-200.

GERBER, N. \& SCHNEIDER, K. (1938). Die praktische Milchprüfung und die Kontrolle von Molkereiprodukten. Bern: Wyss Erben.

Goddard, N. (1981). Agricultural Societies. In G. E. Mingay (Ed.), The Victorian Countryside. 1: Country life, Great Britain, 1837-1901 (pp. 245-59). London: Routledge \& Kegan Paul.

Grantham, G. (1984). The Shifting Locus of Agricultural Innovation in Nineteenth-Century Europe: The Case of the Agricultural Experiment Stations. Research in Economic History, (3), 191-214. 
Harwood, J. (2005). Technology's Dilemma: Agricultural Colleges between Science and Practice in Germany, 1860-1934. Bern: Peter Lang.

HeMINK, G. L. et al. (Eds.) (1979). 75 jaar levensmiddelentechnologie Bolsward. Bolsward:

Vereniging van Afgestudeerden van de Rijks Hogere School voor Levensmiddelentechnologie Bolsward.

Henriksen, I. \& O'Rourke, K. H. (2005). Incentives, Technology and the Shift to Yearround Dairying in Late Nineteenth-Century Denmark. The Economic History Review, 58 (3), 520-54.

Henriksen, I., LAMPE, M. \& Sharp, P. (2011). The Role of Technology and Institutions for Growth: Danish Creameries in the Late Nineteenth Century. European Review of Economic History, 15 (3), 475-93.

Henriksen, I., McLaughlin, E. \& Sharp, P. (2015). Contracts and Cooperation: The Relative Failure of the Irish Dairy Industry in the Late Nineteenth Century reconsidered. European Review of Economic History, 19 (4), 412-31.

HeRnÁNDEZ Adell, I. \& PuJOL, J. (2016). Economic Growth and Biological Innovation:The Development of the European Dairy Sector, 1865-1940. Rural History, 27 (2), 187-212. Jas, N. (2000). Au carrefour de la chimie et de l'agriculture: Les sciences agronomiques en France et en Allemagne 1840-1914. Paris: Éditions des archives contemporaines.

KnibBe, M. (1993). Agriculture in the Netherlands 1851-1950: Production and Institutional Change. Amsterdam: NEHA.

Kooij, P. (2008). Het landbouwonderwijs in de twintigste eeuw. In M. G. J. DuIJVENDAK, E. H. K. KAReL \& P. KooIJ (Eds.), Groen Onderwijs. Terugblik en uitzicht naar aanleiding van het 100-jarig bestaan van de Vereniging voor Hoger Landbouw Onderwijs 1906-2006 (pp. 9-42). Groningen: Nederlands Agronomisch Historisch Instituut.

KREDIET, P. \& STAAL, K.G. (Eds.) (1926). Faarboek voor de zuivelbereiding. Wageningen: Vereeniging van oud-leerlingen der Rijkszuivelschool te Bolsward.

LAMPE, M. \& SHARP, P. (2014). Greasing the Wheels of Rural Transformation? Margarine and the Competition for the British Butter Market. The Economic History Review, 67 (3), 769-92.

LAMPe, M. \& Sharp, P. (2015). Accounting for the Evolution of the Danish Dairy Industry: Bookkeeping, Recordkeeping and the Development of Comparative Advantage. Paper on the Rural History Conference, Girona 2015.

Livingstone, D. N. (2010). Landscapes of Knowledge. In P. Meusberger, D. N. LiVINGSTONE \& H. Jöns (Eds.), Geographies of Science (pp. 3-22). Dordrecht: Springer. MoKyr, J. (2002). The Gifts of Athena: Historical Origins of the Knowledge Economy. Princeton: Princeton University Press.

Molema, M. (2016). Lessons Learned: Organizing Knowledge in the Friesian Dairy Cluster (c. 1885-1904). Low Countries fournal of Social and Economic History, 13 (4), 67-90. 
Nilsson, A. \& Pettersson, L. (2008). The State or the People? Government Policies and Popular Movements in Education and Training in $19^{\text {th }}$ Century Swedish Agriculture. In N.VIVIER (Ed.), The State and Rural Societies: Policy and Education in Europe 17502000 (pp. 215-30). Turnhout: Brepols.

Oberkrome, W. (2009). Ordnung und Autarkie: Die Geschichte der deutschen Landbauforschung, Agrarökonomie und ländlichen Sozialwissenschaft im Spiegel von Forschungsdienst und DFG (1920-1970). Stuttgart: Franz Steiner.

Pazzagli, R. (2008). From Private Initiative to State Intervention: The Origins of Public Agricultural Education in Italy. In N.VIVIER (Ed.), The State and Rural Societies: Policy and Education in Europe 1750-2000 (pp. 231-46). Turnhout: Brepols.

Perren, R. (1995). Agriculture in Depression, 1870-1940. Cambridge: Cambridge University Press.

Rommes, R. N. J. (2014). Voor en door boeren? De opkomst van het coöperatiewezen in de Nederlandse landbouw vóór de Tweede Wereldoorlog. Hilversum: Verloren.

SCHEY, L. T. C. (1903). Handleiding ten gebruike bij den cursus in melkonderzoek. Hoorn: Houdijk.

SchuUrman, A. (2013). Agricultural Policy and the Dutch Agricultural Institutional Matrix during the Transition from Organized to Disorganized Capitalism. In P. MOSER \& T.VARLey (Eds.), Integration through Subordination:The Politics of Agricultural Modernisation in Industrial Europe (pp. 65-85). Turnhout: Brepols.

Segers, Y. \& Hermans, R. (2009). Between Ideology and Science: Higher Agricultural Education in Belgium and the Development of a Catholic Agricultural Network, 18501914. Agricultural History Review, 57 (2), 236-56.

SEgERS, Y. (2016). Economic Clusters, Knowledge Networks and Globalization: Fruit Growing in Dutch Limburg 1850-1940. The Low Countries fournal of Social and Economic History, 13 (4), 93-120.

Skrubbeltrang, F. (1953). Agricultural Development and Rural Reform in Denmark. Roma: Food and Agriculture Organization of the United Nations.

SPAHR VAN DEN HoEK, J. J. (1952). Geschiedenis van de Friese landbouw. Leeuwarden: Friese Maatschappij van Landbouw.

STEERE-Williams, J. (2015). Milking Science for its Worth: The Reform of the British Milk Trade in the Late Nineteenth Century. Agricultural History, 89 (2), 263-88.

Storper, M. (1997). The Regional World:Territorial Development in a Global Economy. New York: Guilford.

Theunissen, B. (2008). Breeding without Mendelism: Theory and Practice of Dairy Cattle Breeding in the Netherlands, 1900-1950. Fournal of the History of Biology, 41 (4). 637-76.

UeKötter, F. (2010). Die Wahrheit ist auf dem Feld: EineWissensgeschichte der deutschen Landwirtschaft. Göttingen: Vandenhoeck \& Ruprecht. 
VAN DER HAAR, J. (1993). De geschiedenis van de landbouwuniversiteit Wageningen. Wageningen: Landbouwuniversiteit Wageningen.

VAN DER WOUdE, R. (2004) Modernisering of marginalisering: Friese landbouworganisaties in de eerste helft van de twintigste eeuw. DeVrije Fries, (84), 181-213.

Van Molle, L. (2005). Kulturkampf in the Countryside. Agricultural Education, 18001940: A Multifaceted Offensive. In C. Sarasúa, P. Schollier \& L. van Molle (Eds.), Land, Shops and Kitchens: Technology and the Food Chain in Twentieth-Century Europe (pp. 139-69). Turnhout: Brepols.

VAN ZANDEN, J. L. (1985). De economische ontwikkeling van de Nederlandse landbouw in de negentiende eeuw 1800-1914. Utrecht: Hes Uitgevers.

VARGA, Z. (2014). Challenges and Responses: Dilemmas of Agrarian Modernization in Interwar Hungary. In L. Fernández-Prieto, J. Pan-Montojo \& M. CABo (Eds.), Agriculture in the Age of Fascism: Authoritarian Technocracy and Rural Modernization, 1922-1945 (pp. 113-35). Turnhout: Brepols.

Wilson J. F. \& Popp, A. (Eds.) (2003). Industrial Clusters and Regional Business Networks in England, 1750-1970. Aldershot: Ashgate.

Zimmermann, C. (2010). Media Use in Rural Society: Medialization in an Historical Perspective. Zeitschrift für Agrargeschichte und Agrarsoziologie, 57 (2), 10-22. 